\title{
Mechanism of Mineral Reactions Inferred from Textures of Impure Dolomitic Marbles from East Greenland
}

\author{
By K. BUCHER-NURMINEN \\ Mineralogical Institute, University of Basel, Bernoullistrasse 30, CH-4056 Basel, \\ Switzerland
}

(Received 15 June 1981; in revised form 1 February 1982)

\begin{abstract}
A BSTRACT
Mineral assemblages and chemical compositions of minerals found in impure dolomitic marbles embedded in gneisses and migmatites of the E. Greenland Caledonian fold belt (Scoresby Sund) suggest that the marbles were metamorphosed near $630^{\circ} \mathrm{C}$ at $5 \mathrm{~kb}$ pressure. The analysis of complex textural and mineralogical relations among minerals such as dolomite, calcite, forsterite, pargasite, chlorite, spinel, diopside and phlogopite led to the conclusion that the major mineralogical features of the rocks were probably caused by sodium metasomatism at constant temperature and pressure. The effect of the inferred sodium metasomatism may be summarized by three schematic reactions all involving modal changes of excess dolomite, calcite, forsterite, chlorite and spinel: (a) nucleation and growth of pargasite, (b) resorption of phlogopite, and (c) growth of pargasite from phlogopite.
\end{abstract}

\section{INTRODUCTION}

Many recently published studies of metamorphic carbonate rocks have concluded that metamorphism occurred in the presence of a fluid phase in excess. This fluid was assumed to be a binary mixture of $\mathrm{CO}_{2}$ and $\mathrm{H}_{2} \mathrm{O}$ and it has been demonstrated in many cases that the composition of such a fluid was controlled by the solid phase assemblage (Trommsdorff, 1972; Rice, 1977; Kerrick, Crawford \& Randazzoo, 1973). Metamorphism therefore occurred in a closed system with pressure and temperature as the only parameters controlling the mineralogy of a rock of given bulk composition. From an analysis of a Norwegian field example of Glassley (1975) concluded that, in relatively small marble lenses embedded in large gneiss masses, the system may become open to volatile and highly soluble components. In addition to pressure and temperature, chemical variables such as the chemical potentials of $\mathrm{CO}_{2}, \mathrm{H}_{2} \mathrm{O}, \mathrm{HF}, \mathrm{Na}_{2} \mathrm{O}, \mathrm{K}_{2} \mathrm{O}$ were shown to be limiting to the solid phase assemblage (see also Tanner, 1976). Metamorphism of systems open to $\mathrm{CO}_{2}$ and $\mathrm{H}_{2} \mathrm{O}$ have been described by Moore \& Kerrick (1976), Hewitt (1973) and Taylor \& O'Neil (1977).

The field study presented in this paper describes mineral assemblages and textural relationships in some impure dolomitic marbles which form thin bands in the vast complex of migmatites and gneisses in the Caledonian fold belt of E. Greenland.

Textural evidence is presented which implies that migration of chemical species occurred during the metamorphic evolution of the rocks. Local mineral reactions were deduced from the textures of silicate-rich clusters. In contrast to previously described examples of metamorphic textures (Carmichael, 1969; Fisher, 1970; Foster, 1981) the local reactions cannot be balanced to a 'net-reaction' conserving all cations except hydrogen on the scale of a thin section. It is concluded that highly soluble alkalies moved on a scale larger than a thin section and that their chemical potentials were externally controlled. 


\section{GENERAL GEOLOGY}

The marbles described in this study form part of a metasedimentary sequence included in a large migmatite and gneiss zone of the Caledonian fold belt of E. Greenland. This zone extends some $80 \mathrm{~km}$ from east to west and about $200 \mathrm{~km}$ from north to south. It is located in the inner parts of the Scoresby Sund and in the Stauning Alper $\left(26^{\circ}\right.$ west and between $70^{\circ}$ and $72^{\circ}$ north). The marbles were found on the occasion of a mapping expedition of the Geological Survey of Greenland (1972) to the southern termination of the migmatite zone (Bucher, 1979). For description and discussion of the various aspects of the regional geology, refer to Henriksen \& Higgins (1976), and Steiger et al. (1979).

The metasedimentary sequence containing the marbles under discussion outcrops on eastern Gaaseland (Scoresby Sund area). Aspects of the local geology have been described by Bucher (1979). The metasediments are interlayered with migmatized gneisses. The characteristic members of the sequence are biotite-garnet-sillimanite-gneisses, amphibolites and various carbonate rocks. Within the metasediments leucogranite sheets and rare cross-cutting granitic dykes are found occasionally. The following mineral assemblages are typical of the non-calcareous rocks: quartz-plagioclase-alkali feldspar-garnet-biotite in migmatite gneisses; quartz-plagioclase-alkali feldspar-garnet-biotite-sillimanite in metapelitic gneisses: plagioclase-hornblende-biotite-garnet-clinopyroxene ( \pm quartz) in amphibolites.

The coexistence of alkali feldspar + sillimanite (Evans, 1965) and of almandine + sillimanite (Richardson, 1968) together with the abundant occurrence of migmatites suggests that temperatures in excess of $650^{\circ} \mathrm{C}$ were reached during the regional metamorphism under medium pressure conditions. While there is very little information on the pressure during metamorphism, the absence of cordierite (Richardson, 1968) and kyanite (Holdaway, 1971) is consistent with pressures above $4 \mathrm{~kb}$ and below $6.5 \mathrm{~kb}$ at $650^{\circ} \mathrm{C}$. An estimate of about 5 $\mathbf{k b}$ is used in this paper, but the uncertainty introduced by the imprecise knowledge of pressure will not affect the conclusions drawn in the paper.

\section{THE PETROGRAPHY OF THE MARBLES}

The E. Greenland marbles are medium-grained rocks. Sheet silicates show no preferred orientation despite the strong folding; this indicates postdeformational crystallization of the observed marble assemblages and argues against the likelihood of some minerals being relics of earlier assemblages. Minerals observed in thin sections include calcite, dolomite forsterite, clinohumite, diopside, amphibole, spinel, chlorite and phlogopite. Modal abundances of minerals have been determined for one typical marble specimen and are listed in Table 1 together with the' calculated bulk chemical composition. Modal calcite greatly exceeds dolomite, but dolomite is present in all rocks examined.

\section{TABLE 1}

Modal composition and calculated bulk chemistry of sample GGU 169570 (total number of points counted 2150)

\begin{tabular}{llllll}
\hline Calcite & 57.9 (vol. per cent) & $\mathrm{SiO}_{2}$ & 13.9 (wt. per cent) & $\mathrm{K}_{2} \mathrm{O}$ & 0.6 (wt. per cent) \\
Dolomite & 10.3 & $\mathrm{Al}_{2} \mathrm{O}_{3}$ & 2.0 & $\mathrm{Na}_{2} \mathrm{O}$ & 0.1 \\
Forsterite & 18.0 & $\mathrm{TiO}_{2}$ & 0.1 & $\mathrm{H}_{2} \mathrm{O}$ & 0.5 \\
Phlogopite & 6.3 & $\mathrm{FeO}$ & 0.8 & $\mathrm{~F}$ & 0.1 \\
Amphibole & 5.6 & $\mathrm{MgO}$ & 17.0 & $\mathrm{CO}_{2}$ & 30.2 \\
Spinel & 0.9 & $\mathrm{CaO}$ & 34.7 & & \\
Chlorite & 1.1 & & & & \\
\hline
\end{tabular}


Olivine (forsterite) occurs as slightly broken crystals and shows only minor late stage serpentinization in most samples. Spinel forms small euhedral green grains; late chloritization has rarely been observed. Small spinel crystals enclosed in calcite are occasionally mantled by dolomite. Amphibole is of about the same grain size as olivine and the sheet silicates (c. 1 to 3 $\mathrm{mm}$ ). Chemical analyses show that two distinct amphiboles are present, one of pargasitic and the other of tremolitic composition. Many of the amphiboles are zoned strongly, both optically and chemically (pargasite core and tremolite rim).

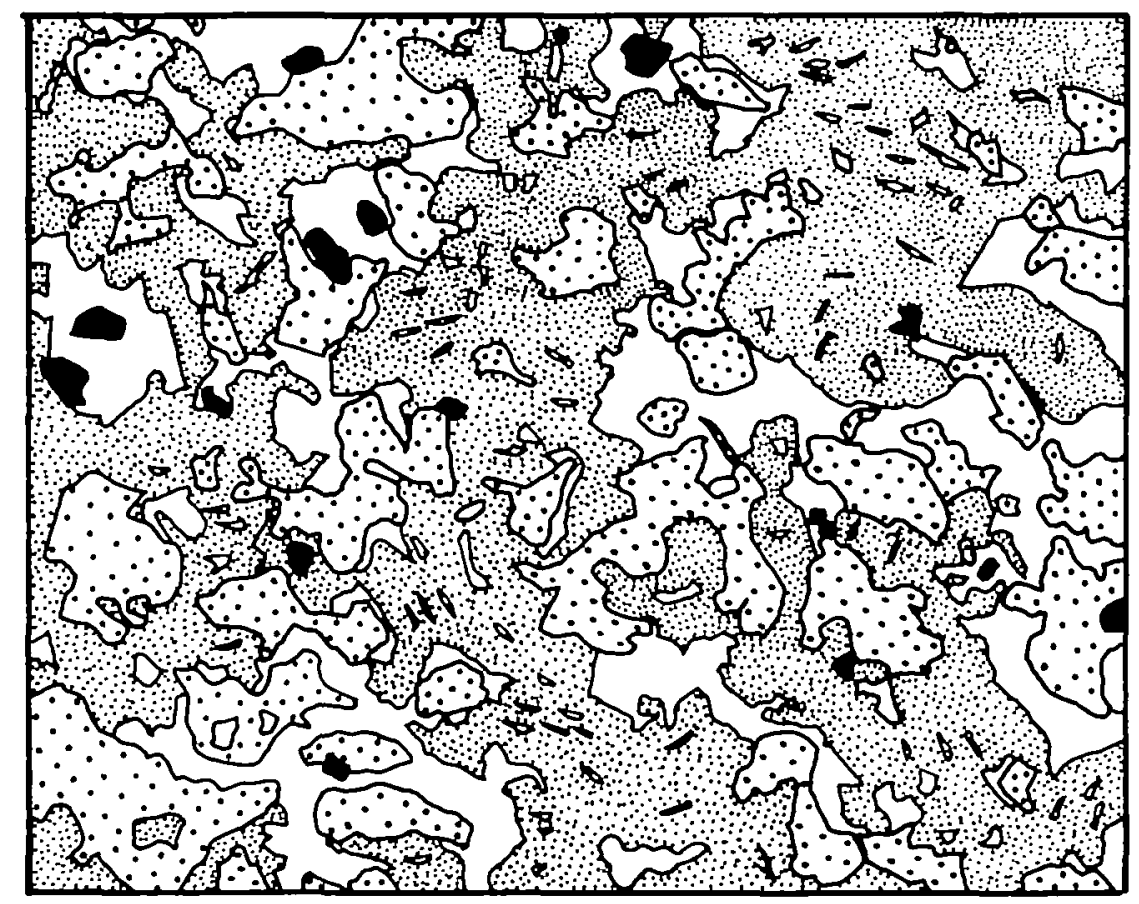

FIG. 1. General texture of GGU 169570. Diagonal of drawing approximately $2 \mathrm{~cm}$. White: dolomite: coarse stippled: silicate minerals; fine stippled: calcite; black: spinel.

The silicate and oxide minerals are found as isolated crystals within the carbonate matrix or are associated in clusters of millimetre size. All the minerals of the list given above may occur in a single homogeneous rock sample with no apparent compositional zoning. The overall mineral assemblage of the rock is distributed among a variety of different local assemblages in the clusters.

The textures are evidence for a number of reactions which have not gone to completion. This suggests that overall chemical equilibrium was not achieved on the scale of thin section. The observed clusters, formed during the growth of metamorphic minerals, were possibly caused by chemical reaction and transport during metamorphism.

Textural examination of these clusters has revealed a number of local mineral reactions:

Dolomite is commonly associated with the silicate clusters (Figs. 1 and 2); otherwise it only occurs as exsolution patches in magnesian calcite in the matrix of the same rock. This textural relationship suggests that dolomite may have formed from silicate + calcite reactions and may not be of primary origin.

Zoned amphibole with parallel overgrowth of small corroded phlogopite flakes and olivine 


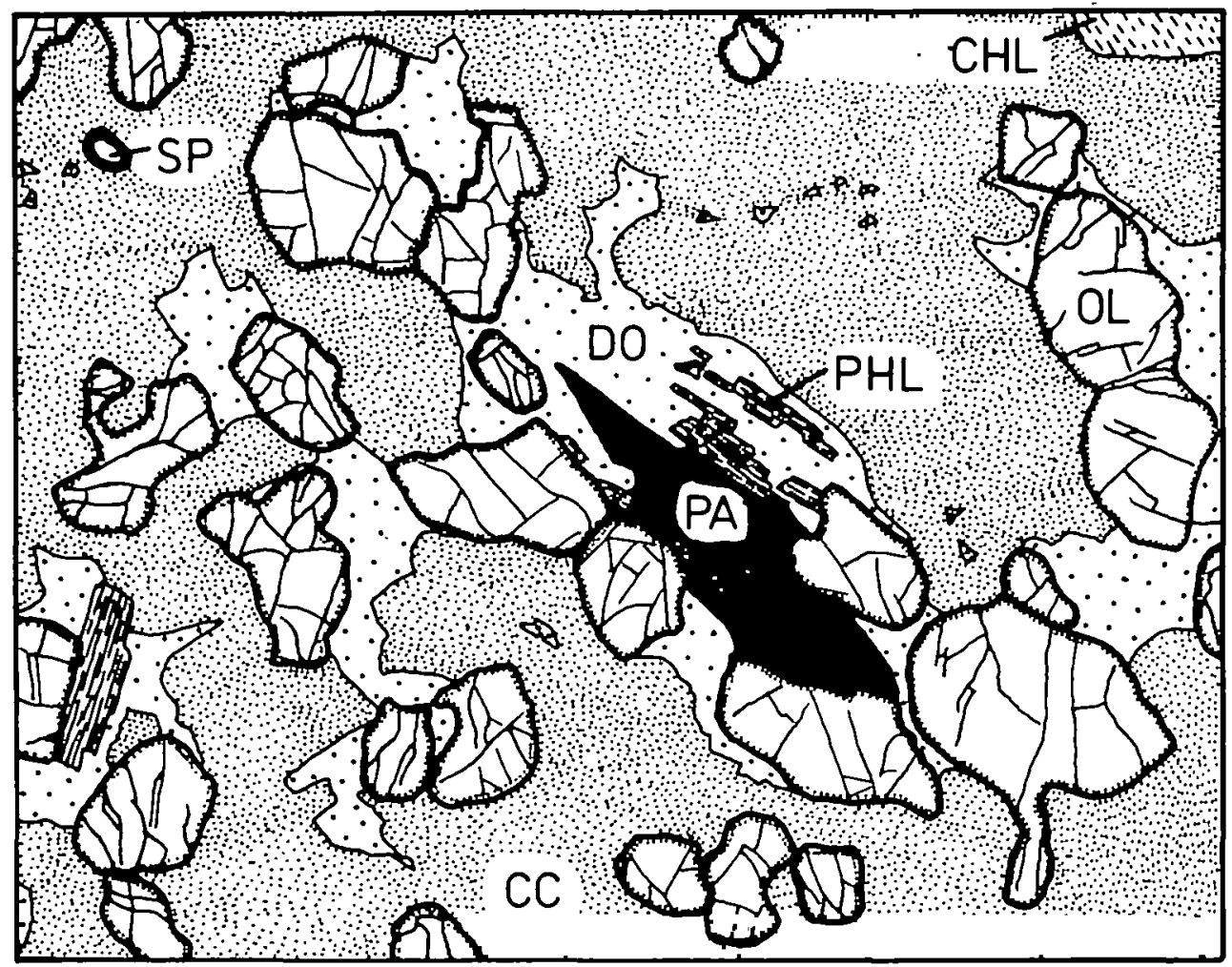

FIG. 2. Detail of Fig. I (GGU 169570). Diagonal $6 \mathrm{~mm}$. Pargasite-dolomite-forsterite-phlogopite cluster in calcite-rich marble.

suggests that a reaction relation exists between pargasite and phlogopite (Figs. 2, 3 and 4). This observation, together with the observed dolomite enrichment in the immediate vicinity of pargasite, may be described by the following relation using the mineral compositions given in Table 2:

TA B LE 2

Composition of phases

\begin{tabular}{lccccccccc}
\hline \multicolumn{1}{c}{ Name } & $\mathrm{CaO}$ & $\mathrm{MgO}$ & $\mathrm{AlO}_{1.3}$ & $\mathrm{SiO}_{2}$ & $\mathrm{HO}_{0.5}$ & $\mathrm{CO}_{2}$ & $\mathrm{NaO}_{0.3}$ & $\mathrm{KO}_{0.5}$ & Symbol \\
\hline Pargasite & 2.0 & 4.0 & 2.7 & 6.3 & 2.0 & - & 0.7 & - & $\mathrm{Pa}$ \\
Phlogopite & - & 5.6 & 2.8 & 5.6 & 4.0 & - & - & 2.0 & $\mathrm{Phl}$ \\
Chlorite & - & 9.7 & 4.6 & 5.7 & 16.0 & - & - & - & $\mathrm{Chl}$ \\
Spinel & - & 1.0 & 2.0 & - & - & - & - & - & $\mathrm{Sp}$ \\
Forsterite & - & 2.0 & - & 1.0 & - & - & - & - & $\mathrm{Fo}$ \\
Diopside & 1.0 & 1.0 & - & 2.0 & - & - & - & - & $\mathrm{Di}$ \\
Tremolite & 2.0 & 5.0 & - & 8.0 & 2.0 & - & - & - & $\mathrm{Cc}$ \\
Calcite & 1.0 & - & - & - & - & 1.0 & - & - & $\mathrm{Do}$ \\
Dolomite & 1.0 & 1.0 & - & - & - & 2.0 & - & - \\
\hline
\end{tabular}

$0.728 \mathrm{Cc}+0.135 \mathrm{Phl}+0.126 \mathrm{Fo}+0.168 \mathrm{CO}_{2}+0.098 \mathrm{NaCl}$ $=0.448 \mathrm{Do}+0.140 \mathrm{~Pa}+0.216 \mathrm{H}_{2} \mathrm{O}+0.270 \mathrm{KCl}$ 


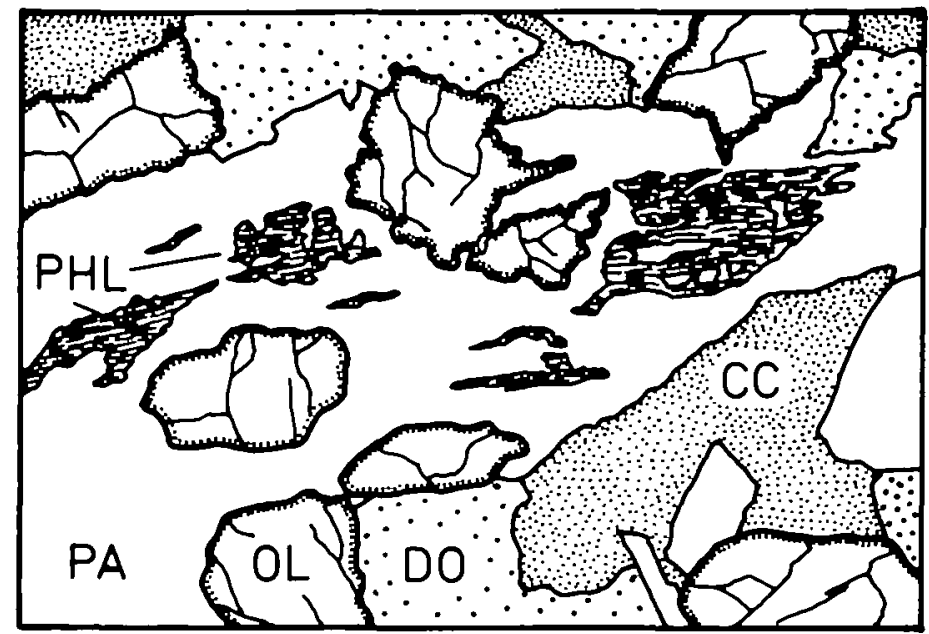

FIo. 3. Texture observed in GGU 169575. Diagonal $1 \mathrm{~mm}$. Partially resorbed phlogopite and forsterite as inclusions in pargasite.

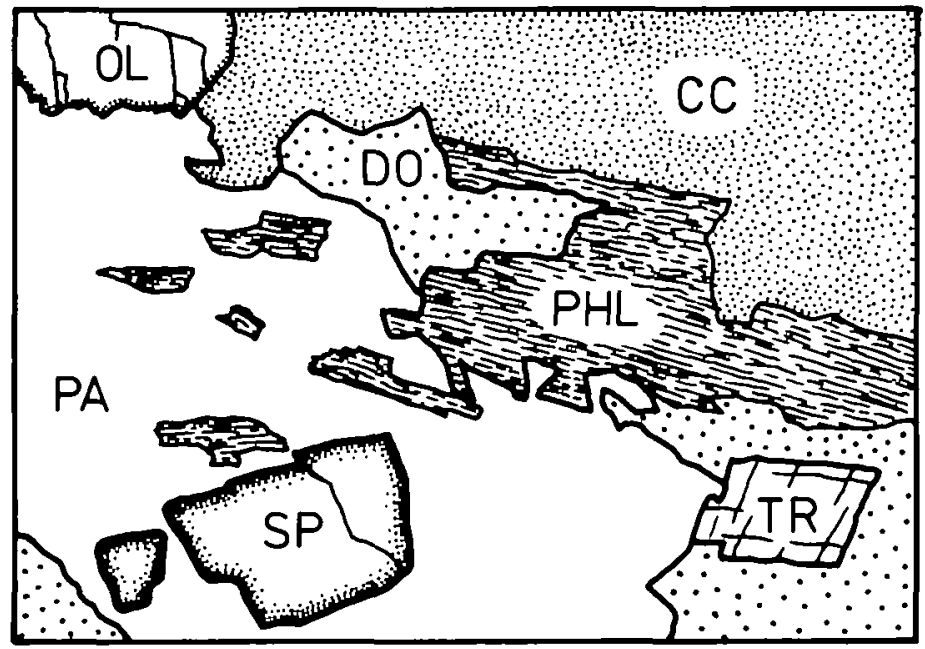

FIo. 4. Texture in GGU 169575. Diagonal $1 \mathrm{~mm}$. Inclusions of spinel and partially resorbed phlogopite in pargasite.

On the other hand, it was observed that spinel may appear in the cluster assemblage permitting the formulation of the following reaction:

$$
\begin{array}{r}
0.163 \mathrm{Cc}+0.045 \mathrm{Phl}+0.003 \mathrm{CO}_{2}+0.028 \mathrm{NaCl}+0.062 \mathrm{HCl} \\
=0.083 \mathrm{Do}+0.040 \mathrm{~Pa}+0.009 \mathrm{Sp}+0.081 \mathrm{H}_{2} \mathrm{O}+0.09 \mathrm{KCl}
\end{array}
$$

The texture of the assemblage calcite + dolomite + chlorite + phlogopite + pargasite (Fig. 6) indicates a reaction relation among these minerals also. It may be described by the following reaction:

$$
\begin{gathered}
0.3206 \mathrm{Cc}+0.1359 \mathrm{Phl}+0.0686 \mathrm{NaCl}+0.2032 \mathrm{HCl} \\
=0.1246 \mathrm{Do}+0.098 \mathrm{~Pa}+0.0252 \mathrm{Chl}+0.0738 \mathrm{H}_{2} \mathrm{O}+0.0714 \mathrm{CO}_{2}+0.2718 \mathrm{KCl}
\end{gathered}
$$

Relict lamellae of phlogopite found in large chlorite flakes in mosaic textures with pargasite and related dolomite support the validity of this reaction. 


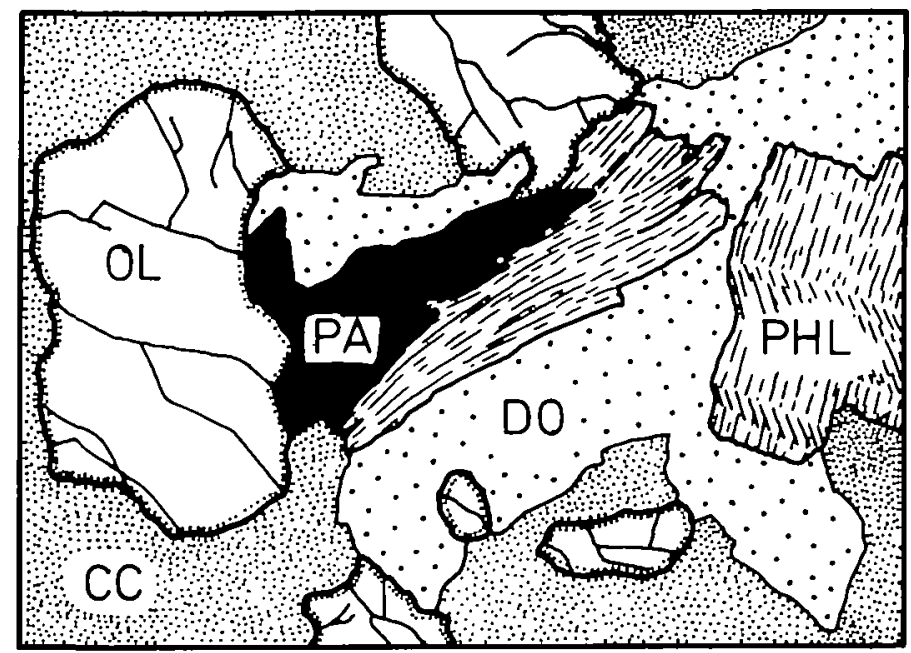

Fio. 5. Texture in GGU 169710. Diagonal $1 \mathrm{~mm}$. Aggregate of small euhedral pargasite replacing phlogopite.

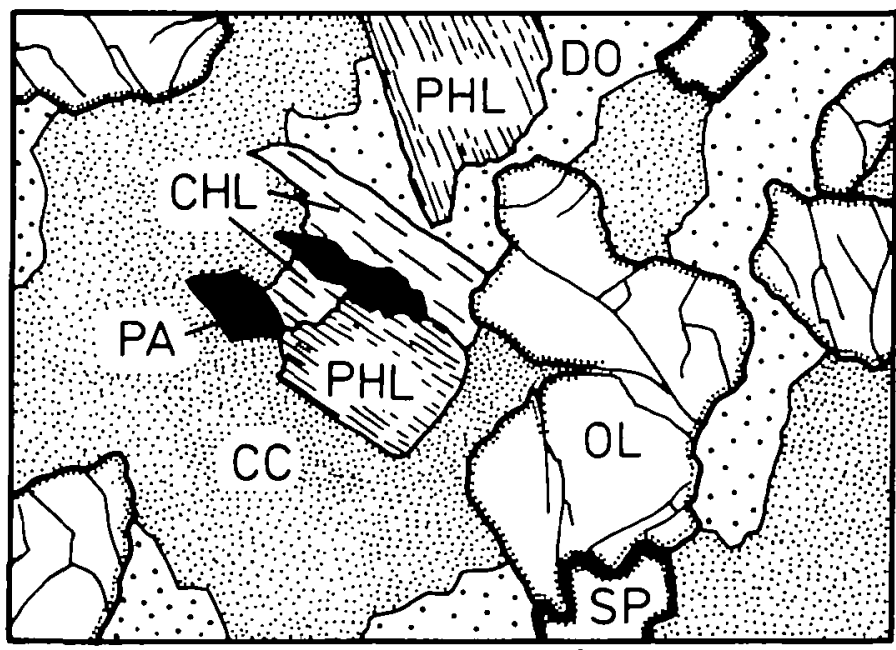

FIG. 6. Texture in GGU 169710. Diagonal $2 \mathrm{~mm}$. Small euhedral pargasite associated with chlorite replacing phlogopite.

The same reaction relation is supported by the observation of chlorite overgrowth in phlogopite inclusions in pargasite.

In phlogopite-free parts of the rock, zoned amphibole overgrows spinel and olivine. The following reaction adequately describes this textural observation:

$$
\begin{aligned}
& 0.239 \mathrm{Cc}+0.126 \mathrm{Fo}+0.027 \mathrm{Sp}+0.027 \mathrm{H}_{2} \mathrm{O}+0.159 \mathrm{CO}_{2}+0.014 \mathrm{NaCl} \\
& =0.199 \mathrm{Do}+0.020 \mathrm{~Pa}+0.014 \mathrm{HCl}
\end{aligned}
$$

It must be noted, however, that spinel and forsterite occur in the same rock as isolated crystals in the carbonate matrix.

Chlorite occurs in three different textures. Radial bundles of chlorite crystals, closely associated with corroded spinel, are interpreted to be of late-stage retrograde origin. Large 
flakes of euhedral chlorite in mosaic textural relation to spinel and forsterite indicate that equilibrium of the reaction

$$
0.4 \mathrm{Cc}+0.57 \mathrm{Fo}+0.23 \mathrm{Sp}+0.8 \mathrm{H}_{2} \mathrm{O}+0.4 \mathrm{CO}_{2}=0.4 \mathrm{Do}+0.1 \mathrm{Chl}
$$

was achieved at a distinct stage during the metamorphic evolution of the rock. However, chlorite in most cases appears to have formed from phlogopite. This observed chloritization of phlogopite is probably not related to a late-stage retrograde reaction as suggested by the mineral chemistry (see later section). The following reaction most adequately describes the texture

$$
\begin{aligned}
& 0.105 \mathrm{Do}+0.023 \mathrm{Phl}+0.043 \mathrm{H}_{2} \mathrm{O}+0.046 \mathrm{HCl} \\
& =0.105 \mathrm{Cc}+0.049 \mathrm{Fo}+0.014 \mathrm{Chl}+0.105 \mathrm{CO}_{2}+0.046 \mathrm{KCl}
\end{aligned}
$$

Syntactic overgrowth of tremolite on pargasite (Fig. 9) as well as needle-shaped tremolite replacing forsterite may have formed according to the reaction

$$
8 \mathrm{Fo}+13 \mathrm{Cc}+9 \mathrm{CO}_{2}+1 \mathrm{H}_{2} \mathrm{O}=1 \mathrm{Tr}+11 \mathrm{Do}
$$

The contribution of this reaction to the texture of the rock is of minor importance.

The local reactions derived in order to describe the observed textures depend on the size of the domain examined. The reactions formulated here refer to the total cluster assemblage. It usually involves a sufficient number of different minerals so that the reactions can be balanced with respect to all species except $\mathrm{NaCl}$ and $\mathrm{KCl}$. However, if the size of the domain is further reduced, the local reactions may involve only two minerals. Reactions can be written by conserving any arbitrarily chosen component common to the two reaction minerals. The textural relations shown on Fig. 2 may serve as an example of a reaction in a subdomain. In this texture, dolomite is closely associated with silicate minerals and may have formed together with pargasite from phlogopite + forsterite + calcite according to reaction 1 as described earlier. However, dolomite occurs also in close textural relation to forsterite only. In order to explain this texture, it is necessary to consider the possible prograde reactions which may produce a forsterite marble. In rocks with excess dolomite there are two prograde reactions in siliceous marbles producing forsterite (Trommsdorff, 1972; Käse \& Metz, 1980):

$$
\begin{gathered}
1 \mathrm{Tr}+11 \mathrm{Do}+13 \mathrm{Cc}+8 \mathrm{Fo}+9 \mathrm{Co}_{2}+1 \mathrm{H}_{2} \mathrm{O} \\
3 \mathrm{Do}+1 \mathrm{Di}=4 \mathrm{Cc}+2 \mathrm{Fo}+2 \mathrm{CO}_{2}
\end{gathered}
$$

Textures resulting from either of these reactions should be different from the one shown in Fig. 1 as well as in Fig. 2. In particular, one would expect to observe dolomite in the carbonate matrix and dolomite depletion in the vicinity of forsterite. It is therefore probable that dolomite formed from forsterite by the magnesium conserved reaction

$$
1 \mathrm{Fo}+2 \mathrm{CaCl}_{2}+4 \mathrm{CO}_{2}+2 \mathrm{H}_{2} \mathrm{O}=2 \mathrm{Do}+\mathrm{SiO}_{2 \mathrm{qq}}+4 \mathrm{HCl}^{*}
$$

This reaction describes the dissolution of forsterite and the precipitation of dolomite at the forsterite-dolomite grain boundary. At the three mineral intersection the calcite-dolomiteforsterite reaction 10 reduces to

$$
1 \mathrm{Fo}+2 \mathrm{Cc}+2 \mathrm{CO}_{2}=2 \mathrm{Do}+1 \mathrm{SiO}_{2 \Perp \mathrm{q}}
$$

* $\mathrm{SiO}_{2 \text { aq }}$ notation adapted from Walther \& Helgeson (1980). 
Within the scale of the thin section, reaction 11 is also coupled with

$$
3 \mathrm{SiO}_{2 \mathrm{qq}}+1 \mathrm{Sp}+4 \mathrm{Do}+4 \mathrm{H}_{2} \mathrm{O}=1 \mathrm{Chl}+4 \mathrm{Cc}+4 \mathrm{CO}_{2}
$$

These two coupled reactions may be combined to the net reaction

$$
1 \mathrm{Sp}+3 \mathrm{Fo}+2 \mathrm{Cc}+4 \mathrm{H}_{2} \mathrm{O}+2 \mathrm{CO}_{2}=1 \mathrm{Chl}+2 \mathrm{Do}
$$

The stoichiometry of equation 13 differs from that of equation 5 because the composition of end member clinochlore was used in equations 12 and 13 for simplicity. This analysis suggests that the chemical potentials of any component of the system $\mathrm{CaO}-\mathrm{MgO}-$ $\mathrm{Al}_{2} \mathrm{O}_{3}-\mathrm{SiO}_{2}-\mathrm{H}_{2} \mathrm{O}-\mathrm{CO}_{2}$ is controlled by the presence of dolomite + calcite + forsterite + chlorite + spinel in the bulk volume of the rock at any given pressure and temperature.

Some general features as deduced from the local reactions may be summarized as follows:

(a) pargasite appears together with dolomite as a reaction product;

(b) phlogopite is consumed by all reactions;

(c) on the scale of a thin section, the reactions are not balanced with respect to sodium and potassium.

\section{MINERAL CHEMISTRY}

Electron microprobe analyses were conducted on the following minerals: calcite, dolomite, olivine, diopside, chlorite, spinel, phlogopite and amphibole. A selection of representative mineral analyses is presented in Tables 3, 4, 5. All analysed minerals were found to have low iron concentrations. The iron-magnesium partitioning among the minerals shows a regular pattern and the order of iron preference over magnesium within the compositional range of the rocks is: Spinel $>$ olivine $>$ clinohumite $>$ pargasite $>$ chlorite $>$ phlogopite $>$ tremolite $>$ dolomite.

\section{Calcite}

The composition of calcite coexisting with dolomite is determined by the temperaturedependent miscibility gap between these two minerals. The extent of the $\mathrm{Ca}-\mathrm{Mg}$ exchange has been used to estimate temperatures of equilibration. Using the equation given by Rice (1977), a mean temperature of $630^{\circ} \mathrm{C}$ with a standard deviation $(1 \sigma)$ of $24^{\circ} \mathrm{C}$ was calculated. Each of the single grain analyses given on Table 3 represents an average of about 10 spot analyses performed on that grain. Sample GGU 169575 yielded a mean temperature of $613 \pm 28^{\circ} \mathrm{C}$ (Bucher, 1979).

TA B LE 3

\begin{tabular}{|c|c|c|c|c|c|c|c|c|c|c|c|c|c|}
\hline \multirow{2}{*}{$\begin{array}{l}\text { Sample } \\
\text { grain* }\end{array}$} & \multicolumn{4}{|c|}{$169570-2$} & \multicolumn{2}{|c|}{$169570-1$} & \multicolumn{2}{|c|}{$169570-3$} & \multicolumn{3}{|c|}{169710} & \multirow{2}{*}{$\frac{169570}{I}$} & 169710 \\
\hline & 1 & 2 & 3 & 4 & I & 2 & 1 & 2 & $I$ & 2 & 3 & & $I$ \\
\hline $\begin{array}{l}\mathrm{CaCO}_{3} \\
\mathrm{MgCO}_{1} \\
\mathrm{FeCO}_{1} \\
\mathrm{MnCO}_{4}\end{array}$ & $\begin{array}{r}93.89 \\
5.86 \\
0.23 \\
0.13\end{array}$ & $\begin{array}{r}91.21 \\
8.14 \\
0.37 \\
0.18\end{array}$ & $\begin{array}{r}92.28 \\
7.85 \\
0.37 \\
0.21\end{array}$ & $\begin{array}{r}93.56 \\
5.59 \\
0.65 \\
0.09\end{array}$ & $\begin{array}{rr}91 & .74 \\
7 & 11 \\
0 & 37 \\
0 & 24\end{array}$ & $\begin{array}{r}91.21 \\
768 \\
0.40 \\
0.16\end{array}$ & $\begin{array}{r}91.75 \\
6.99 \\
0.39 \\
0.16\end{array}$ & $\begin{array}{r}91.21 \\
7.32 \\
0.24 \\
0.07\end{array}$ & $\begin{array}{rr}91 & 83 \\
7 & 21 \\
0 & 37 \\
0 & 19\end{array}$ & $\begin{array}{r}91.04 \\
7.68 \\
0.32 \\
0.16\end{array}$ & $\begin{array}{r}9139 \\
7.57 \\
0.34 \\
0.16\end{array}$ & $\begin{array}{c}54.75 \\
43.05 \\
1.45 \\
0.28\end{array}$ & $\begin{array}{r}54.51 \\
43.14 \\
1.24 \\
0.05\end{array}$ \\
\hline Total & $100 \cdot 10$ & 99.80 & $100 \cdot 71$ & 99.68 & 99.48 & 99.46 & 99.29 & $98 \cdot 84$ & 99.62 & $99 \cdot 20$ & 9947 & 99.53 & 98.94 \\
\hline $\begin{array}{l}\text { mole per } \\
\mathrm{CaCO} \text {, } \\
\mathrm{MgCO} \text {, } \\
\mathrm{FeCO} \text {, } \\
\mathrm{MnCO}\end{array}$ & $\begin{array}{r}92.82 \\
6.87 \\
0.19 \\
011\end{array}$ & $\begin{array}{r}90.00 \\
953 \\
032 \\
0.15\end{array}$ & $\begin{array}{r}90.39 \\
9.12 \\
0.31 \\
0.18\end{array}$ & $\begin{array}{r}92.77 \\
6.59 \\
0.55 \\
0.08\end{array}$ & $\begin{array}{r}9109 \\
8.38 \\
0.32 \\
0.21\end{array}$ & $\begin{array}{r}90.47 \\
9.04 \\
0.35 \\
0.14\end{array}$ & $\begin{array}{r}91.28 \\
8.25 \\
0.33 \\
0.14\end{array}$ & $\begin{array}{r}91.06 \\
8.68 \\
0.21 \\
0.06\end{array}$ & $\begin{array}{rr}91 & 02 \\
8 & 48 \\
0 & 32 \\
0 & 17\end{array}$ & $\begin{array}{r}90.52 \\
9.06 \\
0.28 \\
0.14\end{array}$ & $\begin{array}{r}9065 \\
8.92 \\
0.29 \\
014\end{array}$ & $\begin{array}{rl}51 & 00 \\
47 & 61 \\
1 & 17 \\
0 & 22\end{array}$ & $\begin{array}{r}51.03 \\
47.93 \\
1.00 \\
0.04\end{array}$ \\
\hline Temp. . ${ }^{\circ} \mathrm{C}$ & 590 & 657 & 647 & 582 & 629 & 645 & 626 & 637 & 632 & 646 & 642 & - & - \\
\hline
\end{tabular}

Microprobe analyses of calcite and dolomite

Mear temperature of all 11 cakcites $=630 \pm 24^{\circ} \mathrm{C}$.

* Each analysis represents an average of 10 spot analyses. 


\section{Phlogopite}

The analysed phlogopites are significantly more aluminous than the ideal end member phlogopite (Fig. 7). The compositional departure is essentially parallel to the tschermakite exchange vector. The activity of the exchange component $\mathrm{MgSiAl}^{-1} \mathrm{Al}^{-1}$ is controlled in the rocks under discussion by the coexistence of spinel and forsterite through the equilibrium $\mathrm{MgAl}_{2} \mathrm{O}_{4}+\mathrm{MgSi}_{2 \mathrm{Al}^{-1}}=\mathrm{Mg}_{2} \mathrm{SiO}_{4}$.

At the $630^{\circ} \mathrm{C}$ indicated by calcite-dolomite thermometry and medium pressure $(\sim 5 \mathrm{~kb})$, the Al-content on the basis of 24 anions was measured to be near 2.75 (Table 4). In a similar pressure-temperature regime the Al-content of phlogopite in spinel forsterite marble was determined to be 2.65 (Bucher, 1981). The extent of the tschermak exchange on phlogopite is dependent on temperature and coexisting minerals. In lower grade aluminous marbles, phlogopite is closer to the end member composition. In marbles of the tremolite zone Sanford (1980) found phlogopites with $\mathrm{Al}=2.44$. The composition of the analysed phlogopites (Table 4) suggests that they reached chemical equilibrium with the assemblage spinel and forsterite at temperatures in excess of $600^{\circ} \mathrm{C}$.

\section{TA B LE 4}

Microprobe analyses of chlorite, phlogopite, diopside, olivine and spinel

\begin{tabular}{|c|c|c|c|c|c|c|c|c|c|c|c|c|}
\hline \multirow[b]{2}{*}{ Sample } & \multicolumn{3}{|c|}{ Chlorite } & \multicolumn{2}{|c|}{ Phlogopile } & \multirow{2}{*}{$\frac{\text { Dlopside }}{169570}$} & \multicolumn{3}{|c|}{ Olivine } & \multicolumn{3}{|c|}{ Spinel } \\
\hline & 169570 & 169710 & 169575 & 169710 & 169570 & & 169570 & 169575 & 169710 & 169570 & 169575 & 169710 \\
\hline $\begin{array}{l}\mathrm{S}_{1} \mathrm{O}_{2} \\
\mathrm{~T}_{1} \mathrm{O}_{2}\end{array}$ & 29.83 & 30.20 & 2945 & $\begin{array}{r}40.76 \\
1.11\end{array}$ & $\begin{array}{r}3970 \\
0.77\end{array}$ & $\begin{array}{r}54.88 \\
0.05\end{array}$ & $41 \cdot 17$ & 4228 & 41.91 & & & \\
\hline $\mathrm{Al}_{2} \mathrm{O}$ & 20.98 & $20 \cdot 56$ & 20.73 & 16.54 & $16 \cdot 81$ & 074 & & & & 7002 & 6971 & 69.58 \\
\hline $\mathrm{FeO}+$ & $2 \cdot 18$ & 202 & 2.06 & 1.62 & 1.54 & 0.89 & $6 \cdot 13$ & 625 & $7 \cdot 47$ & 625 & $6 \cdot 10$ & 6.25 \\
\hline $\begin{array}{l}\mathrm{MgO} \\
\mathrm{CaO}\end{array}$ & 32.80 & 3310 & 32.86 & 2502 & $25 \cdot 36$ & $\begin{array}{l}17.99 \\
24.99\end{array}$ & 52.67 & 51.45 & 5011 & 2396 & $24 \cdot 08$ & 2379 \\
\hline $\mathrm{K}_{2} \mathrm{O}$ & & & & 10.33 & 1077 & & & & & & & \\
\hline$F^{2}$ & 03 & 0.4 & 0.15 & 1.42 & 111 & & & & & & & \\
\hline $\mathrm{H}_{2} \mathrm{O} \neq$ & 1250 & 12.50 & $12 \cdot 50$ & $3 \cdot 60$ & 380 & & & & & & & \\
\hline $\begin{array}{l}\text { Total* } \\
\text { Trace }\end{array}$ & $\begin{array}{c}9859 \\
\text { Ti. Mn }\end{array}$ & $\begin{array}{r}98.77 \\
T_{1}, M n\end{array}$ & $\begin{array}{r}9780 \\
\text { TL, Mn }\end{array}$ & $\begin{array}{c}99.78 \\
\mathrm{Na}\end{array}$ & $\begin{array}{c}9938 \\
\mathrm{Na}\end{array}$ & $\begin{array}{c}99 \cdot 52 \\
\mathrm{Na}, \mathrm{Mn}\end{array}$ & $\begin{array}{c}99.98 \\
\text { Ca. Mn }\end{array}$ & $\begin{array}{c}99.98 \\
\mathrm{Ca} . \mathrm{Mn}\end{array}$ & $\begin{array}{c}99.49 \\
\text { Ca. Mn }\end{array}$ & 10023 & 99.89 & 99.62 \\
\hline
\end{tabular}

Numbers of lons on the basis of

\begin{tabular}{|c|c|c|c|c|c|c|c|c|c|c|c|c|}
\hline \multirow[b]{2}{*}{$\begin{array}{l}S_{1} \\
T_{1}\end{array}$} & \multicolumn{3}{|c|}{$36(0, O H)$} & \multicolumn{2}{|c|}{$24(O, O H, F)$} & \multirow{2}{*}{ 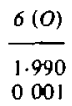 } & \multicolumn{3}{|c|}{$4(O)$} & \multicolumn{3}{|c|}{$4(O)$} \\
\hline & 5.663 & 5719 & 5.627 & $\begin{array}{l}5.690 \\
0.117\end{array}$ & $\begin{array}{ll}5 & 583 \\
0 & 081\end{array}$ & & 0.992 & 1016 & 1.017 & & & \\
\hline Al & 4.694 & 4.590 & 4.670 & 2721 & 2.786 & 0031 & & & & $2 \cdot 004$ & 2001 & 2.003 \\
\hline $\mathrm{Fe}$ & 0.346 & 0.320 & 0.320 & 0.189 & 0.181 & 0.027 & 0.124 & 0.126 & 0152 & 0.127 & 0.124 & 0.129 \\
\hline $\mathrm{Mg}$ & 9.281 & 9.341 & 9.357 & $5 \cdot 206$ & 5.316 & 0972 & 1892 & 1843 & 1.813 & 0.867 & 0874 & 0.866 \\
\hline $\mathrm{Ca}$ & & & & & & 0.971 & & & & & & \\
\hline $\mathrm{K}$ & & & & 1.840 & 1.932 & & & & & & & \\
\hline $\mathrm{F}$ & 0.180 & 0.240 & 0090 & 0.627 & 0494 & & & & & & & \\
\hline $\mathrm{H}$ & 15830 & 15.789 & 15.789 & 3.352 & 3565 & & & & & & & \\
\hline
\end{tabular}

* Total corrected for fluorine, + all Fe as FeO. $\ddagger$ stoichiometric $\mathrm{H}_{2} \mathrm{O}$.

\section{Chlorite}

Excluding late chlorite replacing spinel, the large chlorite crystals analysed (Table 4) are more aluminous than end member chlinochlore $\left(\mathrm{Mg}_{5} \mathrm{Al}_{2} \mathrm{Si}_{3} \mathrm{O}_{10}(\mathrm{OH})_{8}\right)$. Again, as with phlogopite, this compositional departure can be described by an amount of tschermakite exchange on the pure end member clinochlore. The composition of chlorite in the rocks is controlled by two equilibria: (1) $1 \mathrm{Chl}+2 \mathrm{Do}=1 \mathrm{Sp}+3 \mathrm{Fo}+2 \mathrm{Cc}+4 \mathrm{H}_{2} \mathrm{O}+2 \mathrm{CO}_{2}$ and (2) $1 \mathrm{Fo}=1 \mathrm{Sp}+\mathrm{MgSi}_{2} \mathrm{Al}^{-1}$. The octahedral aluminium of the analysed chlorite varies between 2.28 and 2.37 (per 8 tetrahedral sites) and the total excess aluminium (compared to clinochlore) between 0.59 and 0.69 (mean 0.65). It was shown by Rice (1977) that chlorite contains a decreasing amount of $\mathrm{Al}$ with decreasing metamorphic grade. The total excess $\mathrm{Al}$ 
of 0.65 (per 36 anions) corresponds well with the reported breakdown composition of near 0.7 (Widmark, 1980). The composition of the chlorite in the Greenland samples is therefore compatible with the assumption that this mineral represents a member of the high-grade mineral assemblage. Its high $\mathrm{Al}$-content suggests that it reached chemical exchange equilibrium with the remaining constituents of the rock at temperatures of $600{ }^{\circ} \mathrm{C}$ or higher.

\section{Amphiboles}

The microprobe analyses show that two distinct amphiboles are present in these rocks, one of pargasitic, and the other of tremolitic composition (Table 5). (Some compositional

TABLE 5

Variation of amphibole composition in sample GGU 169570

\begin{tabular}{|c|c|c|c|c|c|c|c|c|}
\hline Grain* & $I m$ & $2 m$ & $3 m$ & $4 m$ & \multicolumn{2}{|c|}{10 Tr overgrowth } & $10 \mathrm{rim}$ & I0 core \\
\hline $\mathrm{SiO}_{2}$ & $43 \cdot 58$ & 55.24 & $43 \cdot 26$ & 43.48 & 54.51 & 53.63 & $44 \cdot 59$ & $43 \cdot 73$ \\
\hline $\mathrm{TiO}_{2}$ & 1.49 & 0.29 & 1.49 & 1.53 & 0.33 & 0.37 & $1 \cdot 31$ & 1.49 \\
\hline $\mathrm{Al}_{2} \mathrm{O}_{3}$ & $16 \cdot 25$ & $4 \cdot 50$ & $16 \cdot 51$ & $16 \cdot 27$ & 5.06 & $6 \cdot 50$ & $16 \cdot 55$ & $16 \cdot 27$ \\
\hline $\mathrm{FeOt}$ & 1.88 & 1.34 & 1.93 & 1.76 & $1 \cdot 53$ & $1 \cdot 55$ & 1.68 & 1.89 \\
\hline $\mathrm{MgO}$ & $18 \cdot 23$ & $22 \cdot 75$ & $18 \cdot 26$ & $18 \cdot 53$ & $22 \cdot 42$ & 21.98 & 18.82 & $18 \cdot 52$ \\
\hline $\mathrm{CaO}$ & 13.40 & 13.05 & $13 \cdot 34$ & 13.45 & 13.26 & $13 \cdot 30$ & 13.61 & 13.44 \\
\hline $\mathrm{Na}_{2} \mathrm{O}$ & 1.22 & 0.29 & 1.40 & 1.55 & 0.40 & 0.74 & 1.59 & 1.45 \\
\hline $\mathrm{K}_{2} \mathrm{O}$ & 1.80 & 0.42 & 1.68 & 1.86 & 0.37 & 0.48 & 1.40 & $1 \cdot 71$ \\
\hline $\mathrm{F}$ & 0.89 & 0.53 & 0.85 & 1.00 & 0.60 & 0.60 & 0.90 & 0.90 \\
\hline Total $\ddagger$ & $98 \cdot 21$ & 98.09 & $98 \cdot 34$ & 99.03 & $98 \cdot 25$ & 98.60 & 99.24 & 99.53 \\
\hline \multicolumn{9}{|c|}{ Numbers of lons on the basis of $24(\mathrm{O}, \mathrm{OH}, \mathrm{F})$ including stoichiometric $\mathrm{H}_{2} \mathrm{O}$} \\
\hline $\mathrm{Si}$ & $6 \cdot 117$ & $7 \cdot 550$ & 6.077 & 6.074 & 7.450 & $7 \cdot 302$ & $6 \cdot 193$ & 6.089 \\
\hline $\mathrm{Ti}$ & 0.157 & 0.030 & 0.157 & 0.161 & 0.034 & 0.038 & 0.137 & 0.156 \\
\hline Al & 2.688 & 0.725 & 2.733 & 2.679 & 0.815 & 1.043 & 2.570 & 2.712 \\
\hline $\mathrm{Fe}$ & 0.221 & 0.153 & 0.227 & 0.206 & 0.175 & 0.177 & 0.195 & 0.220 \\
\hline $\mathbf{M g}$ & 3.814 & 4.634 & $3 \cdot 823$ & 3.859 & 4.567 & 4.461 & 3.896 & 3.838 \\
\hline $\mathrm{Ca}$ & 2.015 & 1.911 & 2.008 & 2.013 & 1.942 & 1.940 & 2.025 & 2.002 \\
\hline $\mathrm{Na}$ & 0.332 & 0.077 & 0.381 & 0.419 & 0.106 & 0.195 & 0.428 & 0.391 \\
\hline K & 0.322 & 0.073 & 0.301 & 0.331 & 0.065 & 0.083 & 0.248 & 0.303 \\
\hline$F$ & 0.395 & 0.229 & 0.378 & 0.442 & 0.259 & 0.258 & 0.395 & 0.396 \\
\hline $\mathrm{H}$ & 1.685 & 1.732 & 1.687 & 1.677 & 1.823 & 1.817 & 1.668 & 1.669 \\
\hline $\mathrm{Na} / \mathrm{K}$ & 1.031 & 1.055 & 1.266 & 1.266 & 1.631 & 2.349 & 1.726 & 1.290 \\
\hline
\end{tabular}

* $m$ denotes mean composition of homogeneous grain; $\nmid$ all $\mathrm{Fe}$ as $\mathrm{FeO} ; \ddagger$ total corrected for fluorine.

characteristics of the two amphiboles are shown on Figs. 7-10.) The iron substitution for magnesium is very minor and does not exceed 6 mole per cent. However, there is a marked increase in the Fe-preference with increased Al-substitution on the M2 sites of the amphibole. The M4 positions in the amphibole structure are fully occupied by calcium in all measured amphiboles. The extent of the tschermakite substitution is given on Fig. 7. In the pargasitic amphibole, nearly one $(\mathrm{Mg}, \mathrm{Fe})$ is replaced by one $\mathrm{Al}^{\mathrm{vl}}$ per formula unit and a maximum of 0.8 vacancies on the $A$-sites are replaced by the alkalies $\mathrm{K}$ and $\mathrm{Na}$. There is a good one to one correlation between the sum of the alkalies and the difference between total $\mathrm{Al}^{\mathrm{iv}}$ and tschermak Al ${ }^{\mathrm{lv}}$. Figs. 8 and 9 represent the Al-content of the two amphibole populations.

Tremolite occurs as narrow, optically distinct rims on pargasite, or as small euhedral needles of probably retrograde origin. Tremolite overgrowths are separated from pargasite cores by sharp surfaces characterized by a dramatic decrease of the Al-content towards the rim of the crystals (Fig. 10). The limiting $\mathrm{Al}^{\mathrm{iv}}$ content decreases from 1.5 to 0.7 . The 


\section{PHLOGOPITE}
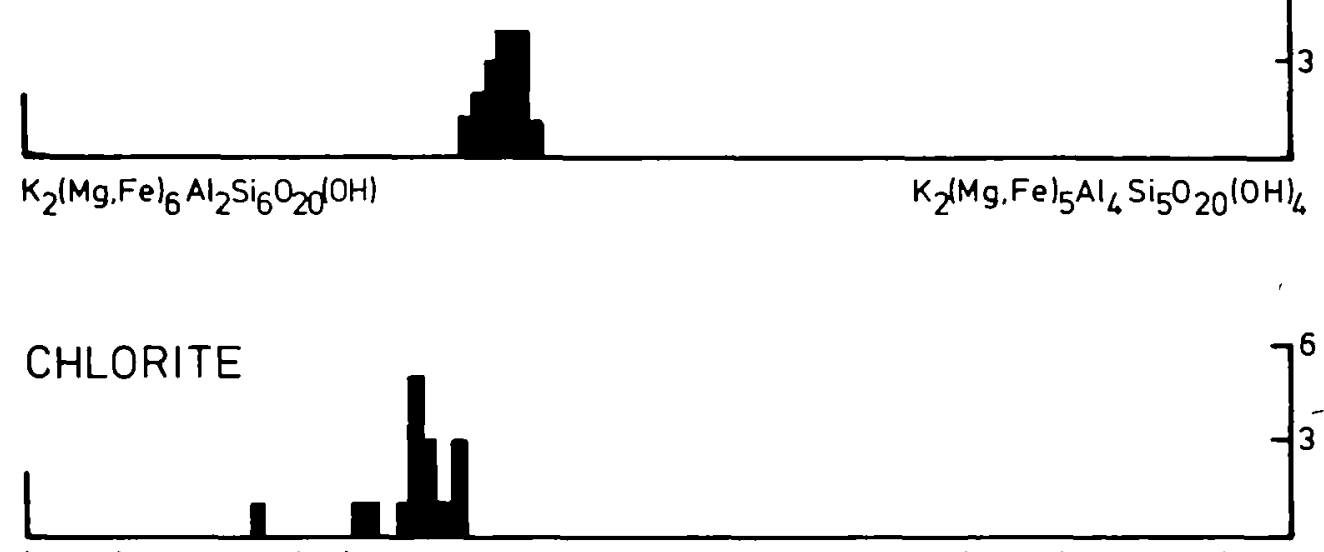

$\left(\mathrm{Mg} . \mathrm{Fe}_{40} \mathrm{Al}_{4} \mathrm{Si}_{6} \mathrm{O}_{20} \mathrm{O}(\mathrm{H})_{46}\right.$

$\left(\mathrm{Mg} . \mathrm{Fel}_{9} \mathrm{Al}_{6} \mathrm{Si}_{5} \mathrm{O}_{20} \mathrm{O} \mathrm{OH}_{46}\right.$

AMPHIBOLE

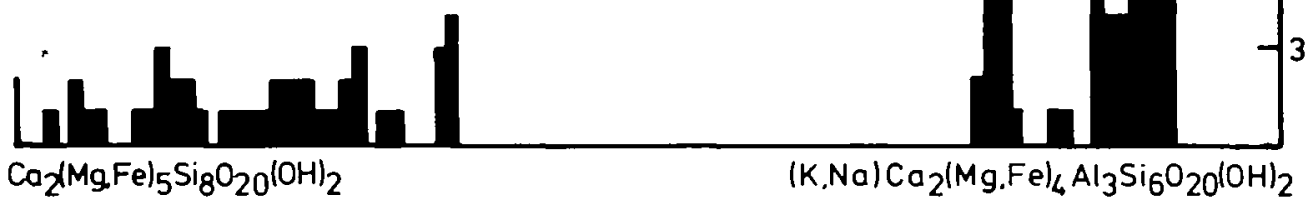

Fio. 7. Histogram representing the extent of tschermak-substitution on the minerals phlogopite, chlorite and amphibole.

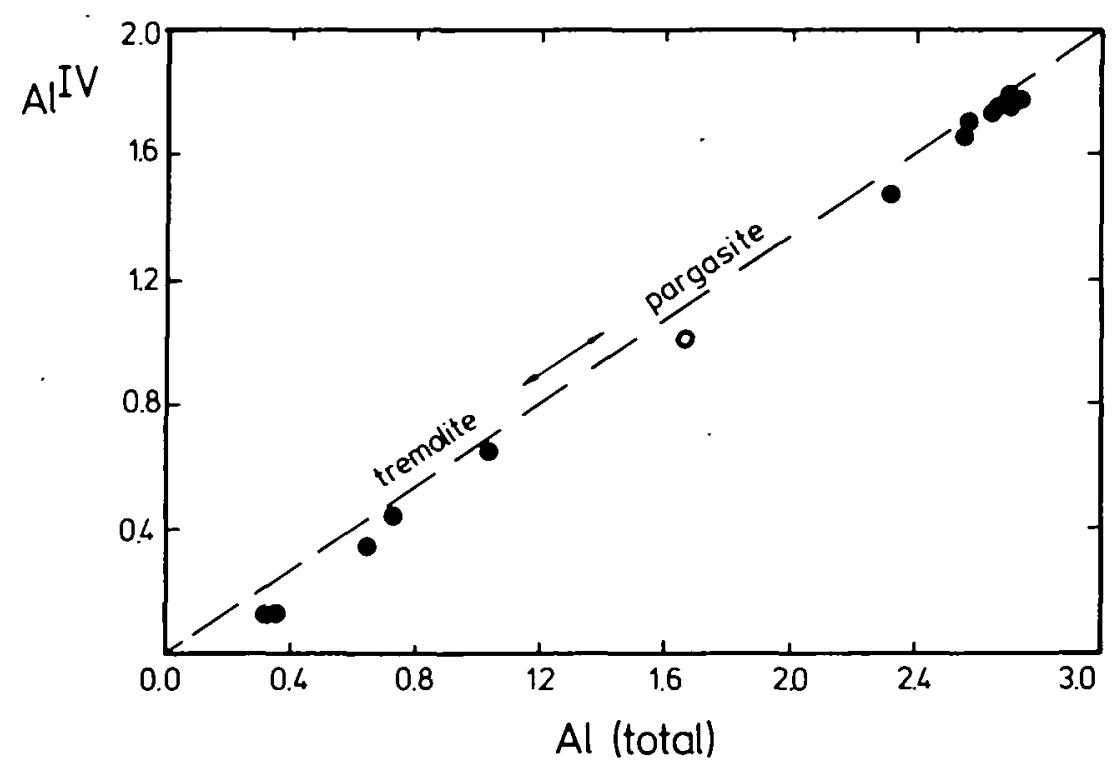

Fig. 8. Amphibole compositions: total aluminium versus tetrahedral aluminium. 


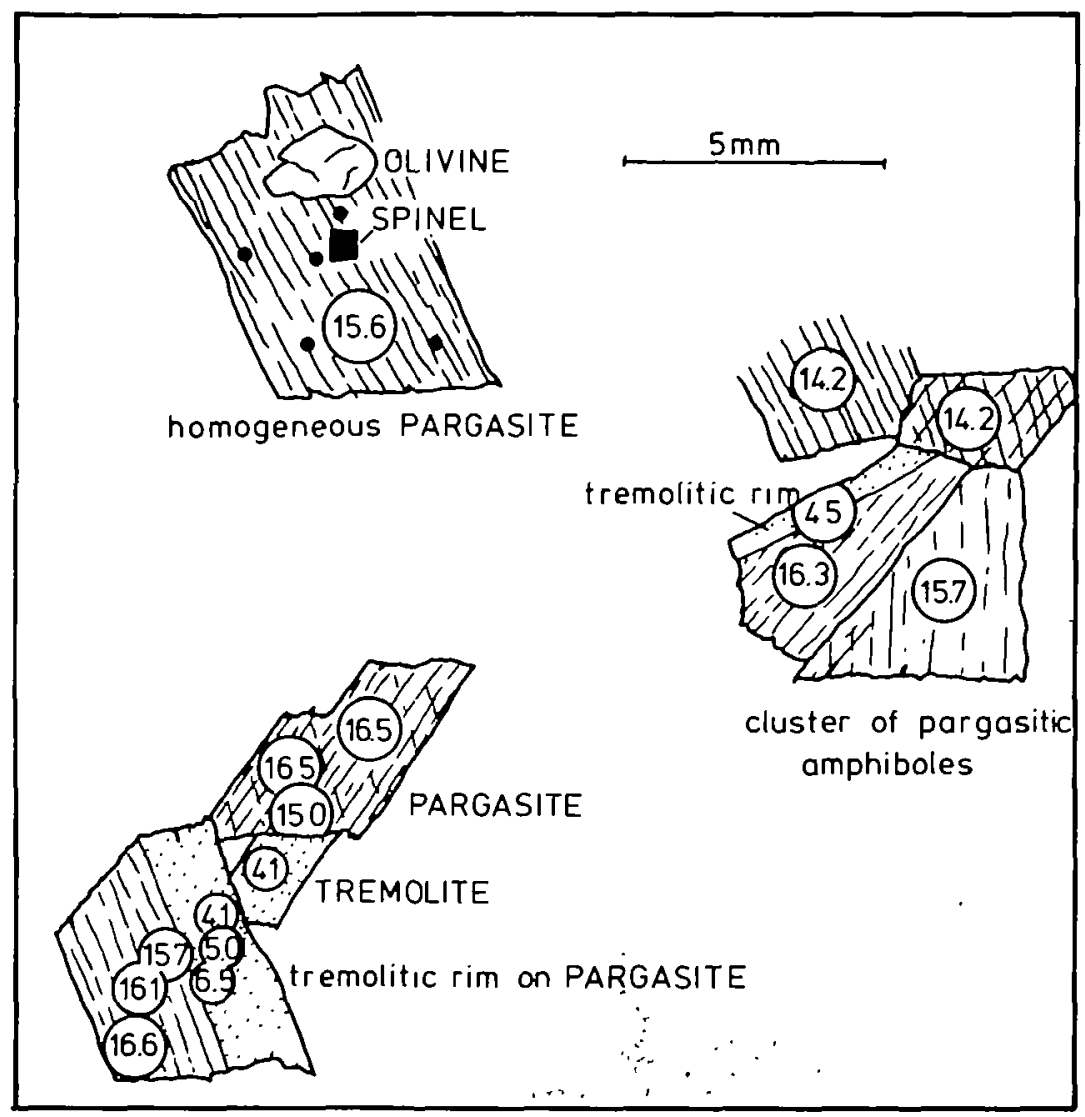

FIG. 9. Aluminium content of amphibole (in wt. per cent $\mathrm{Al}_{2} \mathrm{O}_{3}$ ). Black dots on homogeneous amphibole (upper left) mark analy sed spots.

observed compositional gap is very similar to that described by Rice (1977) from zoned amphibole with pargasitic rims and tremolitic cores: In aluminous dolomites, Al-saturated amphiboles coexisting with spinel contain about 16 wt. per cent $\mathrm{Al}_{2} \mathrm{O}_{3}$ (Rice, 1977; Glassley, 1975). The presence of homogeneous pargasitic amphibole (Fig. 9) in the Greenland rocks can be taken as evidence that these amphiboles belong to the high-grade mineral assemblage of the rock.

\section{Conclusions from the mineral chemistry}

Two important conclusions can be drawn from the observed composition of the minerals:

(1) The composition of the magnesian calcites coexisting with dolomite suggests temperatures of equilibration of about $630^{\circ} \mathrm{C}$.

(2) The composition of amphibole, phlogopite and chlorite indicates that these minerals have formed at relatively high temperatures $\left(>600^{\circ} \mathrm{C}\right)$ and in fact belong to the high-grade mineral assemblage of the rock.

\section{MINERAL REACTIONS AND EQUILIBRIA}

The stability relations among the minerals found in these Greenland marbles may be treated, to a first approximation, in the system $\mathrm{CaO}-\mathrm{MgO}-\mathrm{Al}_{2} \mathrm{O}_{3}-\mathrm{SiO}_{2}-\mathrm{CO}_{2}-\mathrm{H}_{2} \mathrm{O}$. 


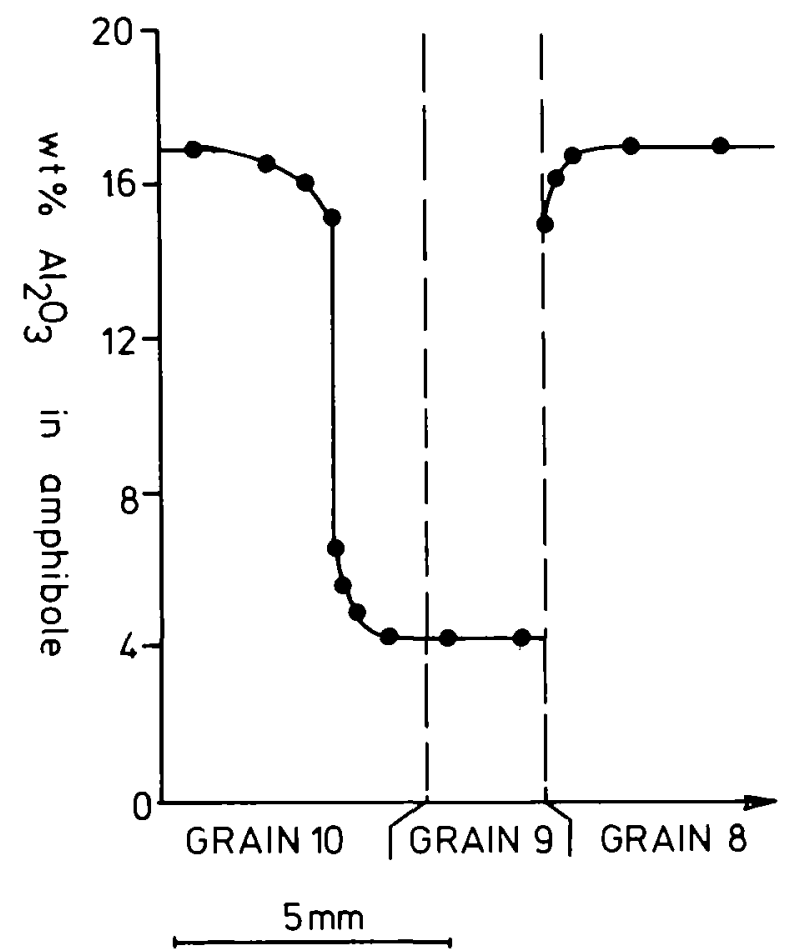

FiG. 10. Chemical profiles across three amphibole grains.

Consequently amphibole will be included in the treatment as tremolite and the phlogopite phase relations will be discussed separately. Fig. 11 shows the equilibria of the reactions relevant to the Greenland marbles at the estimated pressure of 5000 bars.

Because the diagram on Fig. 11 was constructed for pure reaction end member species (except for chlorite which is at its breakdown composition, and calcite whose composition is determined by the miscibility gap with dolomite), the effect of the actual mineral chemistry on the equilibrium curves has to be evaluated first. The only significant solid solution which might affect the position of the equilibrium curves on Fig. 11 is the amphibole solution. The displacement of the equilibrium conditions of, for instance, reaction 9 (Fig. 11) near invariant points $(A)$ and $(B)$ due to the presence of pargasitic amphibole rather than tremolite was calculated to be in the order of $+10^{\circ} \mathrm{C}$ by Rice (1977). Because the pargasitic amphibole of the Greenland rocks is of nearly identical composition to that used in the treatment of Rice, a similar increase of the equilibrium temperature may be expected for reaction 9 (assuming the activity-composition relationship given by Rice adequately models the amphibole solution). The displacement of equilibrium curves for the reactions of Fig. 11 due to the solution of iron into magnesian minerals has been shown to be minimal (Rice, 1977; Bucher, 1981) and can be ignored. The equilibrium curves of Fig. 11 are not likely to shift their positions by more than $\pm 10^{\circ} \mathrm{C}$ as a result of the observed compositional differences between the minerals and the reaction species used in the construction of Fig. 11.

The observed assemblage diopside + dolomite requires high mole fractions of $\mathrm{CO}_{2}$ in the metamorphic fluid. The common six-phase assemblage calcite + dolomite + forsterite + amphibole + chlorite + spinel in homogeneous marbles indicates that the rocks may have equilibrated at conditions of point (A) $\left(5 \mathrm{~kb}, 690^{\circ} \mathrm{C}\right.$ and $\left.X_{\mathrm{Co}_{2}}=0.7\right)$. In the same samples, 


\section{$P=5 \mathrm{~kb} \quad$ EXCESS CALCITE + DOLOMITE}

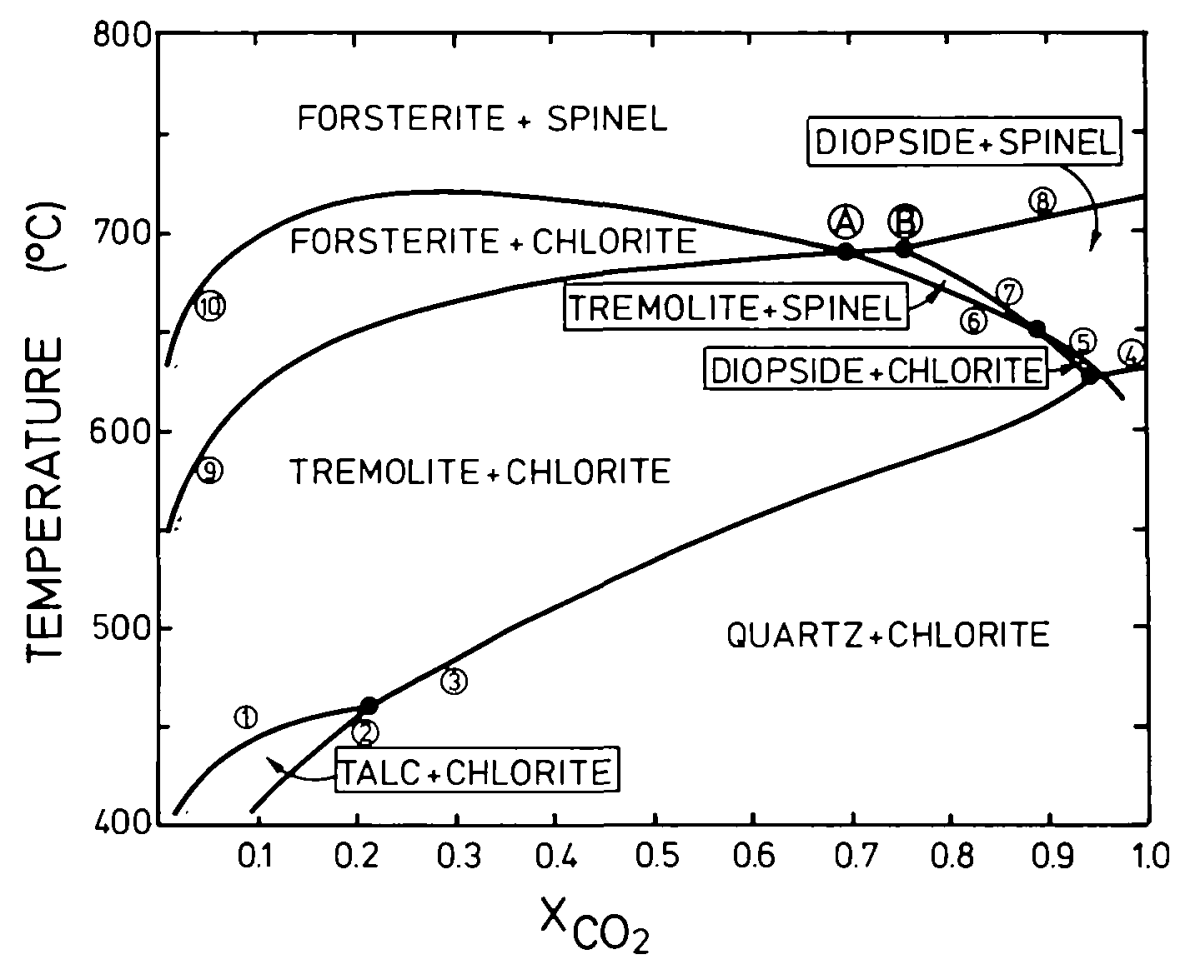

FIG. 11. Isobaric temperature versus $X_{\mathrm{CO}_{2}}$ diagram showing equilibrium conditions for the reactions given on Table 6 for marbles containing calcite and dolomite in excess at $5 \mathrm{~kb}$.

the six-phase assemblage dolomite + calcite + diopside + forsterite + amphibole + spinel is present, indicating conditions of point (B) $\left(5 \mathrm{~kb}, 690^{\circ} \mathrm{C}\right.$ and $\left.X_{\mathrm{CO}_{2}}=0.75\right)$. The equilibration temperatures indicated by the calcite-dolomite thermometry of $630 \pm 24^{\circ} \mathrm{C}$ are slightly

TA B LE 6

Stoichiometries of reactions shown on Fig. 11 and source of data. Compositions of phases and abbreviations given on Table 2

\begin{tabular}{|c|c|c|}
\hline Reaction & & $\begin{array}{l}\text { Source } \\
\text { of data }\end{array}$ \\
\hline (1) & $2 \mathrm{Tc}+3 \mathrm{Cc}=1 \mathrm{Tr}+1 \mathrm{Do}+1 \mathrm{CO}_{2}+1 \mathrm{H}_{2} \mathrm{O}$ & * \\
\hline (2) & $3 \mathrm{Do}+4 \mathrm{Qz}+1 \mathrm{H}_{2} \mathrm{O}=1 \mathrm{Tc}+3 \mathrm{Cc}+3 \mathrm{CO}_{2}$ & * \\
\hline (3) & $5 \mathrm{Do}+8 \mathrm{Qz}+1 \mathrm{H}_{2} \mathrm{O}=1 \mathrm{Tr}+3 \mathrm{Cc}+7 \mathrm{CO}_{2}$ & * \\
\hline (4) & $1 \mathrm{Do}+2 \mathrm{Qz}=1 \mathrm{Di}+2 \mathrm{CO}_{2}$ & * \\
\hline (5) & $20 \mathrm{Chl}+148 \mathrm{Cc}+34 \mathrm{CO}_{2}=57 \mathrm{Di}+91 \mathrm{Do}+46 \mathrm{Sp}+160 \mathrm{H}_{2} \mathrm{O}$ & $\dagger$ \\
\hline (6) & $42 \mathrm{I} \mathrm{Cc}+80 \mathrm{Chl}+193 \mathrm{CO}_{2}=307 \mathrm{Do}+57 \mathrm{Tr}+184 \mathrm{Sp}+583 \mathrm{H}_{2} \mathrm{O}$ & $\dagger$ \\
\hline (7) & $1 \mathrm{Tr}+3 \mathrm{Cc}=1 \mathrm{Do}+4 \mathrm{Di}+1 \mathrm{CO}_{2}+1 \mathrm{H}_{2} \mathrm{O}$ & * \\
\hline (8) & $1 \mathrm{Di}+3 \mathrm{Do}=2 \mathrm{Fo}+4 \mathrm{Cc}+2 \mathrm{CO}_{2}$ & $\ddagger$ \\
\hline (9) & $1 \mathrm{Tr}+11 \mathrm{Do}=8 \mathrm{Fo}+13 \mathrm{Cc}+9 \mathrm{CO}_{2}+1 \mathrm{H}_{2} \mathrm{O}$ & $\S$ \\
\hline (10) & $40 \mathrm{Do}+10 \mathrm{Chl}=40 \mathrm{Cc}+57 \mathrm{Fo}+23 \mathrm{Sp}+40 \mathrm{CO}_{2}+80 \mathrm{H}_{2} \mathrm{O}$ & $\|$ \\
\hline
\end{tabular}

- Slaughter, Kerrick \& Wall (1975).

† Arbitrarily, constrained to be consistent with Rice (1977).

$\ddagger$ Käse \& Metz (1980).

$\S$ Metz (1976).

il Calculated from Widmark (1980). 
below the conditions at point (A) and point (B) and are probably due to dolomite exsolution during the cooling path (Fig. 2).

Textural contact between each possible pair of minerals from the seven listed above has been observed with the exception of chlorite + diopside. This is in agreement with the requirements of the phase diagram of Fig. 11 . Because the assemblage of point $(\mathrm{A})$ and point (B) occur in the same thin section in different silica-rich clusters, it is likely that the composition of the fluid varied on a millimetre scale.

The observed mineral assemblages indicate that the rocks were metamorphosed near $700{ }^{\circ} \mathrm{C}$ in a relatively $\mathrm{CO}_{2}$-rich environment (at the estimated $5 \mathrm{~kb}$ pressure). The compositions of the analysed minerals as well as the assemblages of the pelitic rocks and the occurrence of migmatitic gneisses are consistent with this estimate. The textural relations described in the petrography section and the reactions deduced from these textures may be attributed to isobaric isothermal changes in the mineralogy in response to local fluctuations in the composition of the metamorphic fluid. The nature of these mineralogical changes will be elucidated in the next section.

It has been suggested by Rice (1977) that the composition of amphibole in aluminous dolomites is not necessarily dependent on the composition of the fluid but rather is controlled by the coexisting minerals. Specifically, the tremolite component may be fixed by the assemblage $\mathrm{Fo}+\mathrm{Do}+\mathrm{Cc}+\mathrm{Tr}$, and the tschermakite component by the coexistence of spinel + forsterite (as it is in phlogopite and chlorite) but the remaining major amphibole component edenite appears not to be an independent variable and is instead controlled by the requirements of the Gibbs-Duhem equation. However, as also noted by Rice (1977), introduction of sodium as an aqueous species in the metamorphic fluid to the assemblage $\mathrm{Cc}+\mathrm{Fo}+\mathrm{Sp}$ will cause pargasitic amphibole to precipitate together with dolomite by the reaction (e.g.) $12 \mathrm{Fo}+23 \mathrm{Cc}+3 \mathrm{Sp}+15 \mathrm{CO}_{2}+3 \mathrm{H}_{2} \mathrm{O}+2 \mathrm{Na}^{+}=2 \mathrm{~Pa}+19 \mathrm{Do}+2 \mathrm{H}^{+}$. Thus, introduction of $\mathrm{Na}^{+}$to the system will not change the composition of the amphibole and, more importantly, will limit the appearance or disappearance of pargasite in a given mineral assemblage at constant pressure and temperature.

The observed texture of pargasite overgrowing spinel and forsterite and the intimate association of pargasite with dolomite in an otherwise dolomite-poor rock supports the significance of isobaric isothermal reactions such as the one given above. In addition, observed reaction relations involving phlogopite require the discussion of phase relations in terms of the chemical potentials of arbitrarily chosen potassic and sodic species in the metamorphic fluid. There are many possible ways to tackle this problem. One is to proceed from the two hydrolysis reactions for pargasite and phlogopite respectively (Frantz, Popp \& Boctor, 1981).

Phlogopite: $\mathrm{Phl}+7 \mathrm{HCl}^{\circ}+1.5 \mathrm{H}_{2} \mathrm{O}=\mathrm{KCl}^{\circ}+3 \mathrm{MgCl}_{2}{ }^{\circ}+0.5 \mathrm{Al}_{2} \mathrm{O}_{3}+3 \mathrm{H}_{4} \mathrm{SiO}_{4}$

Pargasite: $\mathrm{Pa}+13 \mathrm{HCl}^{\circ}+4.5 \mathrm{H}_{2} \mathrm{O}=\mathrm{NaCl}^{\circ}+2 \mathrm{CaCl}_{2}^{\circ}+4 \mathrm{MgCl}_{2}^{\circ}+1.5 \mathrm{Al}_{2} \mathrm{O}_{3}$ $+6 \mathrm{H}_{4} \mathrm{SiO}_{4}$

Because the rocks under consideration contain the five minerals dolomite, calcite, forsterite, spinel and chlorite, this mineral assemblage controls the chemical potentials (or activities) of all aqueous species in the above reaction equations except for $\mathrm{NaCl}^{\circ}, \mathrm{KCl}^{\circ}$ and $\mathrm{HCl}^{\circ}$ at a given temperature and pressure. Consequently, the saturation of the rock system with respect to phlogopite or pargasite will depend on the activities of $\mathrm{NaCl}^{\circ}, \mathrm{KCl}^{\circ}$ and $\mathrm{HCl}^{\circ}$ in the coexisting metamorphic fluid. The saturation conditions for phlogopite and pargasite are given on Fig. 12 in terms of the reduced variables, $\log \left(a_{\mathrm{NaCl}} / a_{\mathrm{HCl}}\right)$ and $\log \left(\mathrm{a}_{\mathrm{KC}} / \mathrm{a}_{\mathrm{HCl}}\right)$. Fig. 12 was calculated using the thermochemical data of Franz, Popp \& Boctor (1981). As 


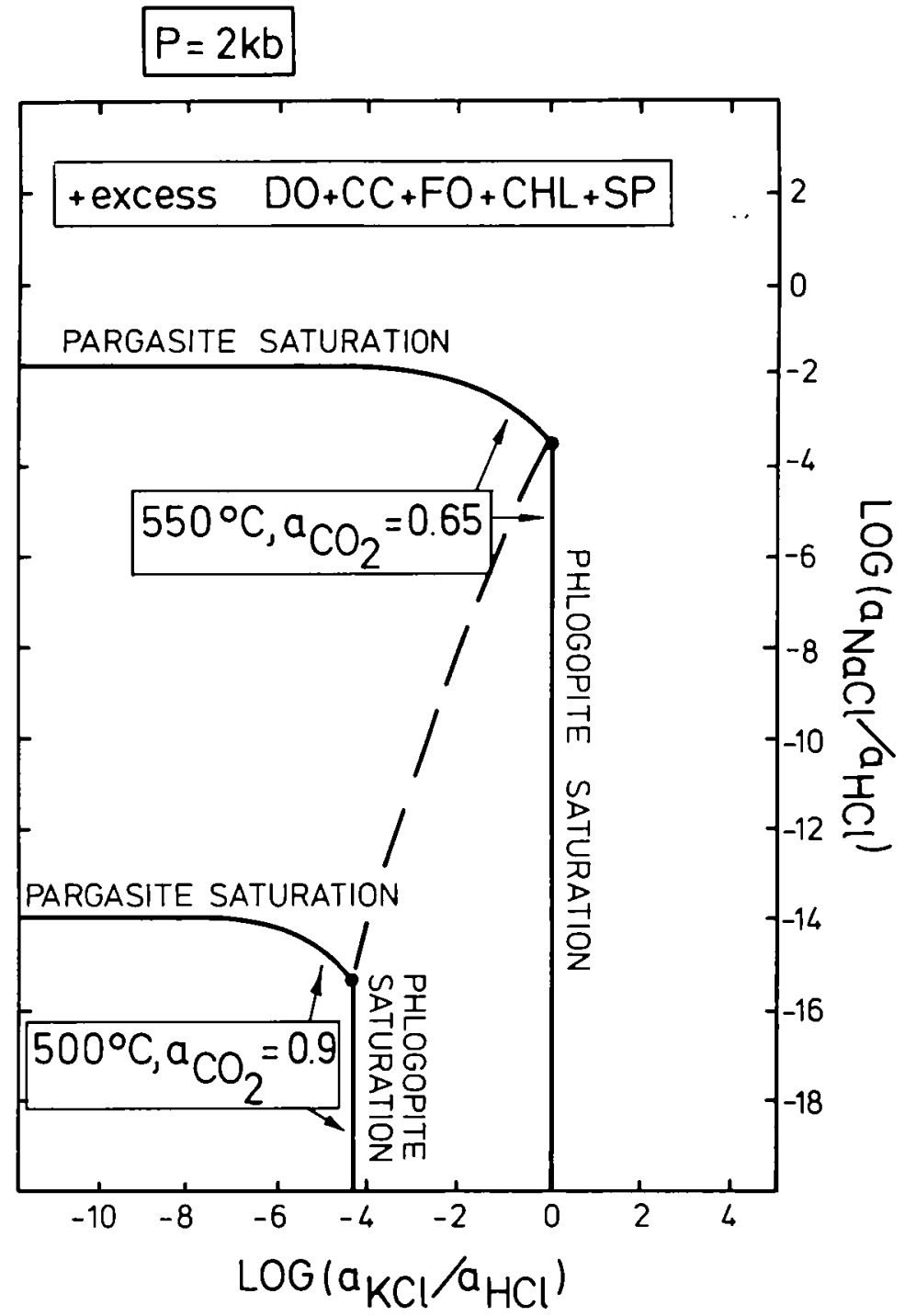

FIG. 12. Saturation conditions for phlogopite and pargasite in the presence of calcite, dolomite, forsterite, chlorite and spinel at $2 \mathrm{~kb}$ and 500 and $550^{\circ} \mathrm{C}$ respectively. Polythermal trace of invariant point $\mathrm{R}$ schematically given by the dashed curve.

experimental data are available for 1 and $2 \mathrm{~kb}$ pressures only, the diagram (Fig. 12) does not apply quantitatively to the Greenland marbles. However, the diagram will be used to visualize the general principles of the observed mineral reactions. Phlogopite and pargasite saturation are shown at two different temperatures in order to predict the temperature effects on the mineral solubilities. Because of constraint of excess dolomite-calcite-forsterite-spinelchlorite at the two temperatures, the $X_{\mathrm{CO}_{2}}$ at equilibrium are different. Note that the above assemblage is metastable at $2 \mathrm{~kb}$ and $500^{\circ} \mathrm{C}$. At $2 \mathrm{~kb}$ and $550^{\circ} \mathrm{C}, X_{\mathrm{CO}_{2}}=0.65$ represents the equilibrium value of reaction 10 (assuming ideal mixing of $\mathrm{CO}_{2}$ and $\mathrm{H}_{2} \mathrm{O}$ ). If phlogopite occurs in the assemblage, $\log \left(\mathrm{a}_{\mathrm{KCl}} / \mathrm{a}_{\mathrm{HCl}}\right)$ is buffered to a finite value (near zero at $550^{\circ} \mathrm{C}$ and $2 \mathrm{~kb})$. If phlogopite is absent, $\log \left(\mathrm{a}_{\mathrm{KCl}} / \mathrm{a}_{\mathrm{HCl}}\right)$ may be at any value below the saturation. 
Similarly, if pargasite is part of the assemblage, $\log \left(a_{\mathrm{NaCl}} / a_{\mathrm{HCl}}\right)$ is controlled by the solid phase assemblage along the pargasite saturation curve. If pargasite is absent, $\log \left(a_{\mathrm{NaCl}} / \mathrm{a}_{\mathrm{HCl}}\right)$ may be at any value below the saturation conditions. In addition, pargasite contains a significant amount of potassium (Table 3). The displacement of the saturation curve due to $\mathrm{Na}$-replacement by potassium in pargasite is schematically given on Fig. 12. Assuming the amphibole with the highest molar $\mathrm{K} / \mathrm{Na}$ ratio is closest to equilibrium with phlogopite (point $R)$, a $\log \left(a_{\mathrm{NaCl}} / a_{\mathrm{HCl}}\right)$ value of about -3.5 is already sufficient for pargasite to occur in the assemblage. With decreasing $\log \left(\mathrm{a}_{\mathrm{KC}} / \mathrm{a}_{\mathrm{HC}}\right)$, it may be expected that pargasite incorporates a decreasing amount of potassium and approaches $\log \left(a_{\mathrm{NaCl}} / \mathrm{a}_{\mathrm{HCl}}\right)$ for potassium-free pargasite asymptotically.

With decreasing temperature, the solubilities of phlogopite and pargasite decrease simultaneously. The polythermal trace of the equilibrium conditions for the coexistence of pargasite and phlogopite is given by the dashed curve on Fig. 12. It might therefore be suspected that the observed formation of pargasite is simply an effect of decreasing temperature. For example, consider an initial solution saturated with phlogopite at $550{ }^{\circ} \mathrm{C}$, and with a $\log \left(\mathrm{a}_{\mathrm{NaCl}} /{ }_{\mathrm{HCl}}\right)$ value somewhere arbitrarily below the saturation with pargasite (for instance at $-8 \cdot 0)$. Along a cooling path some phlogopite will precipitate in order to maintain equilibrium with the fluid (rather than dissolve as suggested by the textures). At a certain given temperature the solution will become saturated with respect to pargasite. Pargasite will then precipitate from the fluid if the rock continues to cool. A crude estimate suggests that about 16.7 grams of pargasite/litre rock can be formed by cooling a rock under the assumption of $\mathrm{NaCl}$-saturation at high temperature and essentially pure water at low temperatures and 2 wt. per cent fluid in the rock containing 80 per cent $\mathrm{CO}_{2}$. This corresponds to a modal increase of $0.6 \mathrm{wt}$. per cent pargasite. Note, however, that this represents a maximum value for the given 2 wt. per cent fluid in the rock. To produce the typical 6 per cent pargasite in the Greenland marbles by this mechanism, about 20 per cent fluid $\left(X_{\mathrm{CO}_{2}}=0.8\right)$ saturated with $\mathrm{NaCl}$ would be necessary to supply the required sodium for the amphibole.

Though it is possible, at least in principle, to produce the observed pargasite isochemically from an initial Na-bearing pore solution by cooling, this mechanism is very unlikely.

Recently Schreyer et al. (1980) described a natural occurrence of Na-phlogopite. Such a mineral represents a potential candidate for a sodium source in the rocks concerned. Schreyer et al. (1980) suggest a 'solvus' relation between $\mathrm{K}$-phlogopite and its $\mathrm{Na}$-analog. At temperatures below $400^{\circ} \mathrm{C}$, K-phlogopite coexisting with Na-phlogopite contains rather high amounts of $\mathrm{Na}_{2} \mathrm{O}$ (up to 1.92 wt. per cent). Because the sodium in the K-phlogopites of the Greenland marbles (temperature near $650^{\circ} \mathrm{C}$ ) is virtually absent, it may be concluded that the micas probably never coexisted with a $\mathrm{Na}$-phlogopite phase. Furthermore the textures described in the section on petrography suggest that pargasite grew directly from $\mathrm{K}$-phlogopite instead.

The observed formation of pargasite together with dolomite at the expense of spinel + forsterite + calcite or phlogopite + calcite may therefore be related to an introduction of sodium to the rock system under discussion. A number of different reaction paths may be deduced from Fig. 12 and can be related to the observed local textures.

(1) An increase of $\log \left(a_{\mathrm{NaCl}} / \mathrm{a}_{\mathrm{HCl}}\right)$ in a phlogopite saturated rock will drive the fluid composition along the phlogopite saturation curve towards point $R$. At point $R$ phlogopite will dissolve and pargasite of the observed composition forms together with dolomite. Relict phlogopite may be overgrown by pargasite (Figs. 2 and 3). A further increase of log $\left(a_{\mathrm{NaCl}} / a_{\mathrm{HC}}\right)$ results in the growth of pargasite with increasing Na-pargasite component along the pargasite saturation curve. 
(2) An increase of $\log \left(a_{\mathrm{NaCl}} / \mathrm{a}_{\mathrm{HCl}}\right)$ in a phlogopite-free part of the rock will result in the formation of pargasite from spinel + forsterite + calcite. Spinel and forsterite may become overgrown by pargasite.

(3) The formation of $\mathrm{K}$-bearing pargasite in one cluster area of the rock operates as a sink for potassium and may result in an incongruent dissolution of phlogopite in a phlogopite-rich area of the section. This mechanism may account for the observed formation of chlorite from phlogopite.

These three mechanisms satisfactorily explain the observed textural relations.

\section{CONCLUSIONS}

It is suggested that the complex textures and apparent 'low variant' mineral assemblages observed in the described marbles are the result of irreversible reactions in response to local fluctuations of fluid composition at constant temperature and pressure. The major driving force for the observed mineralogical changes is deduced to be an externally controlled increase of $\mu_{\mathrm{Na}_{2} \mathrm{O}}$ in the metamorphic fluid. The effect of the inferred sodium metasomatism may be summarized by three schematic reactions all involving modal changes of excess dolomite, calcite, forsterite, chlorite and spinel: (a) nucleation and growth of pargasite, (b) resorption of phlogopite and (c) growth of pargasite from phlogopite.

Although many of the textures involving pargasite and phlogopite have to be classified as reaction textures rather than equilibrium textures, the departure from chemical equilibrium was probably small in the vicinity of an individual cluster as indicated by the compositions of the minerals, the $\mathrm{Fe}-\mathrm{Mg}$-distribution and the absence of incompatible phases under the given conditions. Small gradients for $\mu_{\mathrm{K}_{2} \mathrm{O}}$ developed between different local assemblages as a consequence of the formation of $\mathrm{K}$-bearing pargasite. It is possible but difficult to prove that all potassium released by the breakdown of phlogopite was quantitatively redistributed into pargasite. No constraints in the form of coupled reactions involving aqueous species and transport (Carmichael, 1968; Sanford, 1980) could be established for the amount of $\mathrm{Na}_{2} \mathrm{O}$ component transported on a large scale within the system considered. This is because the source of the sodium responsible for the observed mineralogical changes could not be identified within the rock volume examined. Similar non-constrained alkali-metasomatism has been documented by Tanner (1976), Wood (1979), Glassley (1975) and Tanner \& Miller (1980).

Chemical potential gradients existed for the components $\mathrm{Na}_{2} \mathrm{O}$ and $\mathrm{K}_{2} \mathrm{O}$ only because all other components were controlled by the assemblage $\mathrm{Do}+\mathrm{Cc}+\mathrm{Fo}+\mathrm{Chl}+\mathrm{Sp}$ throughout the rock. However, despite the fact that all remaining components are controlled by the solid phase assemblage, the minerals calcite, dolomite, forsterite, chlorite and spinel were nevertheless involved in the mineralogical changes that occurred during the resorption of phlogopite and the nucleation and growth of pargasite in response to sodium metasomatism. The textures suggest that the growing pargasite takes its components from all available neighbouring mineral phases. The excess $\mathrm{MgO}$ which becomes available during this process leads to the formation of a second product minerah dolomite. Similar reaction mechanisms for mineral growth and resorption were proposed by Wood (1979).

\section{ACKNOWLEDGEMENTS}

For constructive criticism of the first version of this contribution I am indebted to Giles Droop. For his assistance during field work I would like to thank Heiko Oterdoom. This paper is published with the permission of the Director of the Geological Survey of Greenland.

The critical reviews of Paul Metz and Gerd Hoschek are gratefully acknowledged. I thank Bob Vocke for his helpful and constructive comments on the revised version. 


\section{REFERENCES}

Bucher-Nurminen, K., 1979. The migmatites, granites and meta-sediments of Danmark $\varnothing$ and adjacent areas of Milne Land and Gáseland, East Greenland Caldeonian fold belt. Rapp Gronlands geol. Unders. 84.

- 1981. Petrology of chlorite-spinel marbles from north-western Spitzbergen (Svalbard). Lithos, 14, $203-13$.

1982. On the mechanism of contact aureole formation in dolomitic country rock by the Adamello intrusion (N-Italy). Am. Miner. in press.

Carmichael, D. M., 1969. On the mechanism of prograde metamorphic reactions in quartz-bearing pelitic rocks. Contr. Miner. Petrol. 20, 244-67.

Evans, B. W., 1965. Application of a reaction-rate method to the breakdown equilibria of muscovite and muscovite plus quartz. Am. J. Sct. 263, 647-67.

Fisher, G. W., 1970. The application of ionic equilibria to metamorphic differentiation: an example. Contr. Miner. Petrol. 29, 91-103.

Foster, C. T., 1981. A thermodynamic model of mineral segregations in the lower sillimanite zone near Rangeley, Maine. Am. Miner. 66, 260-77.

Frantz, J. D., Popp, R. K., \& Boctor, N. Z., 1981. Mineral-solution equilibria. V. Solubilities of rock-forming minerals in supercritical fluids. Geochim. cosmochim. Acta, 45, 69-77.

Glassley, W. E., 1975. High grade regional metamorphism of some carbonate bodies: significance for the orthopyroxene isograd. Am. J. Sci. 275, 1133-63.

Henriksen, N., \& Higgins, A. K., 1976. East Greenland Caledonian fold belt. In: Escher, A., \& Watt, W. S. (eds.) Geology of Greenland, The Geological Survey of Greenland, Copenhagen, 182-246.

Hewitt, D. A., 1973. The metamorphism of micaceous limestones from south-central Connecticut. Am. J. Sci. Cooper Vol. 273-A, 444-69.

Holdaway, M. J., 1971. Stability of andalusite and the aluminium silicate phase diagram. Ibid. 271, 97-131.

Käse, H.-R., \& Metz, P., 1980. Experimental investigation of the metamorphism of siliceous dolomites. IV. Equilibrium data for the reaction: 1 diopside +3 dolomite $=2$ forsterite +4 calcite $+2 \mathrm{CO}_{2}$. Contr. Miner. Petrol. 73, 151-4.

Kerrick, D. M., Crawford, K. E., \& Randazzo, A. F., 1973. Metamorphism of calcareous rocks in three roof pendants of the Sierra Nevada, California. J. Petrology, 14, 303-25.

Metz, P., 1976. Experimental investigation of the metamorphism of siliceous dolomites. III. Equilibrium data for the reaction: 1 tremolite +11 dolomite $\rightleftharpoons 8$ forsterite +13 calcite $+9 \mathrm{CO}_{2}+1 \mathrm{H}_{2} \mathrm{O}$ for the total pressures of 3000 and 5000 bars. Contr. Miner. Petrol. 58, 137-48.

Moore, J. N., \& Kerrick, D. M., 1976. Equilibria in siliceous dolomites of the Alta Aureole, Utah. Am. J. Sci. 276, 502-24.

Rice, J. M., 1977. Contact metamorphism of impure dolomitic limestone in the Boulder Aureole, Montana. Contr. Miner. Petrol. 59, 237-59.

Richardson, S. W., 1968. Staurolite stability in a part of the system Fe-Al-Si-O-H. J. Petrology 9, 467-88.

Sanford, R. F., 1980. Textures and mechanism of metamorphic reactions in the Cockeysville Marble near Texas, Maryland. Am. Miner. 65, 654-69.

Schreyer, W., Abraham, K., \& Kulke, H., 1980. Natural sodium phlogopite coexisting with potassium phlogopite and sodian aluminian talc in a metamorphic evaporite sequence from Derrag, Tell Atlas, Algeria. Contr. Miner. Petrol. 74, 223-33.

Slaughter, J. D., Kerrick, D. M., \& Wall, V. J., 1975. Experimental and thermodynamic study of equilibria in the system $\mathrm{CaO}-\mathrm{MgO}_{\mathrm{B}} \mathrm{SiO}_{2}-\mathrm{H}_{2} \mathrm{O}-\mathrm{CO}_{2}$. Am. J. Scl. 275, 143-62.

Steiger, R. H., Hansen, B. T., Schuler, Ch., Bär, M. T., \& Henriksen, N., 1979. Polyorogenic nature of the southern Caledonian fold belt in East Greenland: an isotopic age study. J. Geol. 87, 475-95.

Tanner, P. W. G., 1976. Progressive regional metamorphism of thin calcareous bands from the Moinian rocks of N.W. Scotland. J. Petrology, 100-34.

— \& Miller, R. G., 1980. Geochemical evidence for loss of $\mathrm{Na}$ and $\mathrm{K}$ from Moinian calc-silicate pods during prograde metamorphism. Geol. Mag. 117, 267-75.

Taylor, B. E., \& O'Neil, J. R., 1977. Stable isotope studies of metasomatic Ca-Fe-Al-Si skarns and associated metamorphic and igneous rocks, Osgood Mountains, Nevada. Contr. Miner. Petrol. 63, 1-49.

Trommsdorf, V., 1972. Change in T-X during metamorphism of siliceous dolomitic rocks of the Central Alps. Schweiz. miner. petrogr. Mitt. 52, $1-4$.

Walther, J. V., \& Helgeson, H. C. S., 1980. Description and interpretation of metasomatic phase relations at high pressures and temperatures: 1. Equilibrium activities of ionic species in nonideal mixtures of $\mathrm{CO}_{2}$ and $\mathrm{H}_{2} \mathrm{O}$. Am. J. Sci. 280, 575-606.

Widmark, T., 1980. The reactions chlorite + dolomite $=$ spinel + forsterite + calcite + carbon dioxide + water. Contr. Miner. Petrol. 72, 175-9.

Wood. R. M., 1979. A re-evaluation of the blueschist facies. Geol. Mag. 116, 191-201. 